\title{
The antiquity of tuberculosis in Hungary: the skeletal evidence
}

\author{
Antónia Marcsik/+ , Erika Molnár, László Szathmáry* \\ Department of Anthropology, University of Szeged, H-6701 Szeged, P.O.Box 660, Hungary *Department of Evolutionary \\ Zoology and Human Biology, University of Debrecen, Hungary
}

The analysis of the skeletons of past human populations provides some of the best biological data regarding the history of significant diseases such as tuberculosis. The purpose of this study is to present the pathological alterations of the bones in this disease deriving from the ancient time of the territory of the Hungarian Great Plain on the basis of the earlier references and new cases. The bone changes in tuberculosis were mainly manifested in the vertebrae and less frequently in the hip, however, further alterations were observed on the surface of the endocranium and the ribs.

Key words: skeletal tuberculosis - osteoarcheological samples - Hungary

The anthropological study of infectious diseases in antiquity is complex and challenging. The interplay of many variables - host resistance, pathogen virulence, cultural practices, ecological settings, malnutrition, crowding - needs to be considered.

Accurate interpretation depends on proper methodology; adequate sample size, accurate age and sex determination, careful recording of the lesion's localisation, thorough knowledge of cultural background are highly important.

The skeletal material, deriving from different archaeological periods, housed at the Department of Anthropology (University of Szeged), Hungary, has been investigated from paleopathological point of view for a long time. Among paleopathological cases the study of specific infectious disease such as tuberculosis has been especially emphasised, for this disease was among the most important selective factors in human populations in antiquity. Some results regarding the morphological changes and the paleoepidemiology of tuberculosis as well as the analysis of DNA of Mycobacterium tuberculosis complex have been published and are available elsewhere (Haas et al. 1999, 2000, Marcsik \& Pálfi 1999, Marcsik et al. 1999, Pálfi et al. 1999, Pálfi \& Marcsik 1999, Pálfi 2002, Donoghue et al. 2005, Molnár et al. 2005).

The purpose of this study is to present the pathological alterations of the bones in tuberculosis deriving from the ancient time of the territory of the Great Hungarian Plain on the basis of published data and new cases.

\section{MATERIALS AND METHODS}

The new series involved in the investigation were dated to the I-V (Sarmatian Age/1590 specimens), V-VI (German-Gepid Period/552 specimens), VI-IX (Avar Age/

Financial support: NKFP (5/081.2001), the National Scientific Research Foundation (OTKA grant T049614)

${ }^{+}$Corresponding author: marcsik@bio.u-szeged.hu

Received 20 July 2006

Accepted 16 October 2006
484 specimens), X-XIII (Hungarian Coquest and Arpad's era/667 specimens), and XIII-XVII (Arpad's era and Middle Ages/483 specimens) centuries AD. The skeletal material is housed at the Department of Anthropology (Szeged) and in other museums in the Hungary (the earlier data of the number of specimens investigated for $\mathrm{TB}$ is in the study of Pálfí and Marcsik 1999).

The paleopathological investigation was carried out using macroscopic observation and radiographic methods on the basis of published literature (Morse 1961, Aufderheide \& Rodriguez-Martin 1998, Ortner 2003).

For paleopathological diagnosis the most important features were taking into consideration.

\section{Spinal tuberculosis}

Localisation - It is found mainly in the lower thoracic and upper lumbar vertebrae. The central and anterior portions of the vertebral bodies are the most common sites of tubercular destruction. The focus enlarges with the formation of new tubercles and onset of caseation. Tuberculous infection rarely involves the transverse processes, pedicles, lamina, or spinous processes of the vertebrae.

Number of vertebrae - Infrequently involves more than one to four vertebrae, complete destruction of one or more vertebral bodies and associated intervertebral disks often occurs.

Bone regeneration - Is usually very minimal, the trabeculae surrounding the trabecular abscess may become sclerotic.

Collapse and angular kyphosis as the prominent morphological features - As a result of the extensive trabecular and cortical destruction without new bone formation, collapse of the involved vertebral bodies almost invariably occurs. The anterior portion of the vertebral body is usually most seriously involved and unequal collapse results in an angular posterior deformity or kyphosis. The degree of angulation is very marked in the midthoracic region and less so when the collapse occurs in the cervical or lumbar regions. Body bridging or fusion of the collapsed vertebral bodies is not very common (the bony bridging is apparently due to ossification of the paravertebral ligaments). 
The trace of extravertebral cold abscesses - Mostly in the lower thoracic and lumbar area.

\section{Tuberculosis of the joints}

Osteopenia - Deossification of the bones distal and proximal to the joint. Erosion on marginal edge of the bones and destruction of the subchondral bone.

The shape and edge of periarticular destructive lesions - Frequently these are of oval shape with well marked edges and without periosteal reaction.

\section{Frequency of the sequestrum formation - Rare.} knee.

Bony ankylosis - May take place, particularly in the

In some cases the joint is not affected while the metaphysis and adjacent portion of the diaphysis are extensively involved. In the most severe cases, secondary pathological deformities can be noticed.

Tuberculous process can occurs in other bones (ribs, sternum, long bones, skull, tubular bones of the hands and feet), however, the frequency of them is very rare.

\section{RESULTS}

The major part of the cases of skeletal tuberculosis from the ancient time of the territory of the Great Hungarian Plain has already been published in review studies (Marcsik \& Pálfi 1999, Pálfi \& Marcsik 1999, Pálfi 2002) and in other papers (Marcsik \& Vékony 1982, Marcsik 1998, 2003a, b, Marcsik \& Hegyi 2004, Molnár et al. 2005). However, as a result of further paleopathological investigations the number of the cases has been increased (Table).

On the basis of published data (mentioned above) and new cases (Table), the bone changes in tuberculosis were mainly manifested in the vertebrae, less frequently in the hip, with additional alterations observed on the surface of the endocranium, the ribs. The most common site of the vertebral tuberculosis is the thoracic vertebrae. There is a collapse and ankylosis in this region, the anterior portion with the osteolytic lesions of the bodies is most seriously involved and the unequal collapse resulted in angular posterior deformity (kyphosis). Second site of the tuberculous process is in the first lumbar vertebra and then in the lumbosacral part (with osteolytic lesions and periosteal reaction and in one case with fusion between L5 and sacrum). Total number of skeletal tuberculous lesions involve these regions in $75 \%$ (this may be because it houses the skeleton's largest mass of trabecular bone), in some cases with gibbus formations and in five specimens with the traces of cold abscess (Marcsik \& Pálfi 1999, Pálfi \& Marcsik 1999, and Table). The prominent features of the cold abscess is a pathological remodelling and fusion of the lumbosacral region and irregular antemortem erosions on the ventral surface of the sacrum. In $25 \%$ of skeletal tuberculosis involve the hip (the acetabulum, the femoral head and neck is completely or partially

TABLE

Evidence of skeletal tuberculosis with typical lesions - New cases

\begin{tabular}{|c|c|c|c|}
\hline $\begin{array}{l}\text { Site and } \\
\text { archaeological period }\end{array}$ & $\begin{array}{l}\text { Grave number of } \\
\text { specimens in tuberculosis }\end{array}$ & $\begin{array}{l}\text { Type of } \\
\text { tuberculosis }\end{array}$ & References \\
\hline $\begin{array}{l}\text { Kiskundorozsma-Daruhalom } \\
\text { (VII-VIII centuries) } \\
\text { No }=94\end{array}$ & Grave 176 , male & $\begin{array}{l}\text { Spine (thoracic, lumbar } \\
\text { vertebrae and sacrum with } \\
\text { tuberculous abscess) }\end{array}$ & - \\
\hline $\begin{array}{l}\text { Felgyõ-Ürmös tanya } \\
\text { (VIII century) } \\
\text { No }=64\end{array}$ & Grave 205 , female & $\begin{array}{l}\text { Spine (thoracic and } \\
\text { lumbar vertebrae) }\end{array}$ & Maczel 2003 (PhD thesis) \\
\hline $\begin{array}{l}\text { Orosháza-Béke tsz } \\
\text { (VIII century) } \\
\text { No }=98\end{array}$ & Grave 63 , male & Hip & - \\
\hline $\begin{array}{l}\text { Ároktõ-Csík gát } \\
\text { (VIII-IX centuries) } \\
\text { No }=228\end{array}$ & $\begin{array}{l}\text { Grave } 74, \text { female } \\
\text { Grave } 80, \text { male }\end{array}$ & $\begin{array}{l}\text { Spine (thoracic and } \\
\text { lumbar vertebrae) }\end{array}$ & - \\
\hline $\begin{array}{l}\text { Magyarhomoróg-Kónyadomb } \\
\text { (X-XII centuries) } \\
\text { No }=368\end{array}$ & Grave 94 , female & Spine (thoracic vertebrae) & Szigeti 2001 (diplomawork) \\
\hline $\begin{array}{l}\text { Derekegyháza-Ibolyás domb } \\
\text { (XI-XII centuries) } \\
\text { No }=56\end{array}$ & Grave 6 , male & Spine (thoracic vertebrae) & Rácz 2004 (diplomawork) \\
\hline $\begin{array}{l}\text { Nagylak-Határsáv } \\
\text { (XII-XIII centuries) } \\
\text { No }=243\end{array}$ & $\begin{array}{l}\text { Grave } 12, \text { female } \\
\text { Grave } 111 \text {, female }\end{array}$ & $\begin{array}{l}\text { Hip } \\
\text { lumbar (sacrum with } \\
\text { tuberculous abscess) }\end{array}$ & Erdõsi 2000 (diplomawork) \\
\hline $\begin{array}{l}\text { Nyárlõrinc-Hangár út } \\
\text { (XII-XIV centuries) } \\
\text { No }=483\end{array}$ & Grave 82 , female & Spine (thoracic vertebrae) & Balázs 2005 (diplomawork) \\
\hline
\end{tabular}


destroyed, while a periosteal new bone formation can be seen on proximal shaft of the femur), the knee, the ribs and the surface of endocranium and in certain cases some parts of the pleura is calcified (Pálfi \& Marcsik 1999, Molnár et al. 2005). In one specimen, the spina ventosa is associated with spinal tuberculosis (Marcsik \& Vékony 1982), and in another case tuberculous lesions of the spine healed by fusion (with severe kyphosis) could have resulted in a paralytical condition as a consequence of Pott's paraplegia (Marcsik et al. 1999). In an adult male skeleton calcified pleura (DNA of M. tuberculosis complex) was associated with ankylosing spondylitis (Pálfi et al. 1999).

From the I-V (Sarmatian Period) and the V-VI centuries (German Period) AD there is no evidence of skeletal tuberculosis, only endocranial patterns can be considered in some cases (especially in the III-IV centuries) (Marcsik \& Szathmáry 2002). However, it must be noted that endocranial lesions may have several etiologies.

In the VI-IX centuries the number of cases of typical skeletal tuberculosis is increasing. In earlier studies (Marcsik \& Pálfi 1999, Pálfi \& Marcsik 1999) also refer to the fact, that the majority of the tuberculous cases in Hungary belong to the skeletons dated back to the VII-IX centuries. Skeletal tuberculosis is recorded in 15 cases of 1988 specimens (Pálfi \& Marcsik 1999), and in 5 new cases of 484 individuals (Table). During these centuries, the Avar Empire ruled the Carpathian Basin, the territory of which was convenient for agriculture and animal husbandry. Life circumstances in the Late Avar Period were typified by larger agricultural settlements, high population density, poverty (suggested by archaeological data), which may have aided the development and spread of tuberculosis. Since the Avar people relied on agriculture and animal husbandry, $M$. tuberculosis, $M$. bovis or other non-specific Mycobacteria may have participated in the infections (Haas et al. 1999, 2000, Marcsik \& Pálfi 1999, Pálfi \& Marcsik 1999).

Regarding the skeletons dated to the X century, on the basis of the earlier studies (Marcsik \& Pálfi 1999, Pálfi \& Marcsik 1999) and the present investigation there is no typical morphological evidence of skeletal tuberculosis (total number of specimens investigated is 1082). However, atypical morphological alterations, such as superficial vertebral changes, endocranial lesions, periostitis on the ribs, suggest that tuberculosis might have been present in the 10th century also (Maczel 2003). The number of endocranial lesions and periostitis on the ribs are very rare.

Donoghue et al. (2005) analysed the DNA of M. leprae from the samples dated to X century. Two samples (without any changes of skeletal tuberculosis) from the X century (East Hungary - the site is Püspökladány) were positive for DNA of M. tuberculosis complex. Thus, the suspicion that tuberculosis indeed existed in Hungary during the $\mathrm{X}$ century is proved.

In the XI-XIII centuries few cases of typical osseous tuberculosis has already been found (Pálfi \& Marcsik 1999, Marcsik 2003a, b). Of 1930 specimens 5 cases were recorded with tuberculosis. In the Table new cases of spinal tuberculosis are presented: 4 cases of 667 individuals (X-XIII centuries) (Erdõsi 2000, Szigeti 2001, Rácz 2003) (Fig. 1).

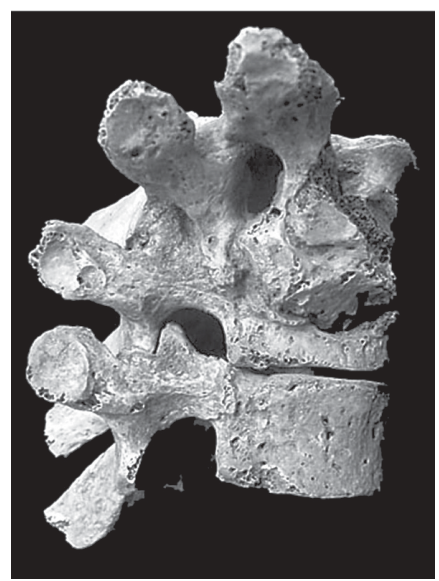

Fig. 1: spinal tuberculosis. The affection of the upper thoracic vertebrae resulted in the collapse of T2 and ankylosis of T1-3. Site: Magyarhomoróg-Kónyadomb, X-XI centuries grave No. 94, female, adult.

The frequency of skeletal tuberculosis has been increasing during the XIII-XVII centuries. According to the study of Pálfi and Marcsik (1999) 11 cases of 1152 skeletons are noticed, and in a newly studied osteological series (XII-XVI centuries) 1 case of 483 was recorded with spinal tuberculosis (Balázs 2005 - Fig. 2). These cases are showing alterations of the vertebras and atypical changes on the ribs.

The Bácsalmás series dated to XVI-XVII centuries is especially significant from paleopathological point of view. After the paleopathological study of the 166 skeletons, paleomicrobiological analysis of 46 skeletal samples (with typical or atypical tuberculous lesions and without lesions) was performed. From these 15 samples - with high prevalence in males and children - were positive for the DNA of M. tuberculosis complex. This result indicates that tuberculosis may have been frequent in this population, probably due to an increased susceptibility to infectious diseases as a consequence of various factors (Molnár et al. 2005).

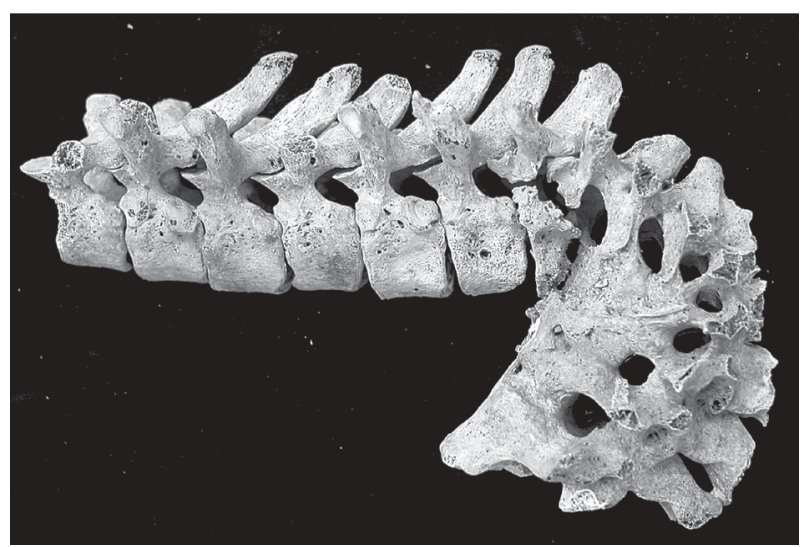

Fig. 2: spinal tuberculosis. The destruction of the lower thoracic and the upper lumbar vertabrae resulted in collapse of T7-12 and ankylosis of T8-L1-2, sharp angular kyphosis between the thoracic and lumbar region. Site: Nyárlõrinc-Hangár út, XII-XVI centuries grave No. 82, female, adult. 


\section{DISCUSSION}

Summing up the results of the earlier and present investigations the following can be stated.

The most cases of skeletal tuberculosis are manifested in the spine with characteristic alterations such as destruction and collapse of vertebrae, in few cases with kyphotic angulation and the traces of prevertebral cold abscess.

Tuberculosis of the hip joint is the second most frequent skeletal lesion after tuberculous spondylitis: total or partial destruction of the femoral head and acetabulum with perforations and exposure of porotic spongiosa.

Tuberculous dactylitis (spina ventosa) of the proximal phalanx of the big toe is recorded in one case and in one specimen the disease is supposed to have caused alterations in knee (with ankylosis).

Reactive periostitis of the pleural surface of the ribs, endocranial lesions might refer to a tuberculous process. It is very important to emphasize that these changes can be developed in other disease as well.

The patterns of osseous tuberculosis are corresponded with the proposed by literature especially in the cases of spinal and hip tuberculosis. Regarding the localisation, the results are also corresponded with literature: vertebral tuberculosis is the most common and most characteristic lesion. Tuberculosis of the hip joint is the second of most frequent skeletal lesion after tuberculous spondylitis. Involvement of other bones in tuberculosis is rare.

The analysis of the DNA of $M$. tuberculosis is very important. In the cases of typical patterns (collapse, angular kyphosis, caries formations) it confirms the diagnosis of tuberculosis established on morphological pictures. However, the analysis of the DNA is the most important if the morphological patterns show the initial tuberculosis and the atypical occurrence.

In the Hungarian Great Plain, on basis of the typical morphological alterations and DNA analysis, the skeletal tuberculosis has been widespread in the VII-IX centuries. Due to skeletal lesions, the presence of tuberculosis has not been proved in the $\mathrm{X}$ century. The occurrence of the disease in this century has only been testified by DNA analysis of the M. tuberculosis complex. After XI century, the number of cases with typical morphological alterations has been increasing.

It seems that skeletal tuberculosis on the Hungarian Great Plain emergenced in the VII century. However, it must be emphasized that the investigation of further skeletal samples can modify this results.

\section{REFERENCES}

Auferheide AC, Rodríguez-Martin C 1998. The Cambridge Encylopedia of Human Paleopathology, Cambridge University Press, Cambridge, 478 pp.

Balázs J 2005. Paleopatológiai vizsgálatok egy XII-XVI. századi széria (Nyárlõrinc Hangár út) leletein, Diplomawork, Department of Anthropology, Szeged, 73 pp.

Donoghue HD, Marcsik A, Matheson C, Vernon K, Nuorala E, Molto JE, Greenblatt ChL, Spigelman M 2005. Co-infection of Mycobacterium tuberculosis and Mycobacterium leprae in human archaeological samples: a possible explanation for the historical decline of leprosy. Proc $R$ Soc $B$ 04PB0582: 1-6.

Erdõsi Gy 2000. Egy 12-13. századi embertani anyag klasszikus feldolgozása, Diplomawork, Department of Anthropology, Szeged, $97 \mathrm{pp}$.

Haas ChJ, Zink A, Molnár E, Marcsik A, Dutour O, Nerlich GA, Pálfi Gy 1999. Molecular evidence for tuberculosis in Hungarian skeletal samples. In GY Pálfi, O Dutour, J Deák, I Hutás (eds), Tuberculosis Past and Present, Golden Book Publisher, Budapest, p. 385-395.

Haas ChJ, Zink A, Molnár E, Reischl U, Marcsik A, Ardagna Y, Dutour O, Pálfi Gy, Nerlich AG 2000. Molecular evidence for different stages of tuberculosis in ancient bone samples from Hungary. Am J Phys Anthropol 113: 293-304.

Maczel M 2003. "On the traces of tuberculosis" Diagnostic criteria of tuberculous affection of the human skeleton and their application in Hungarian and French anthropological series, PhD thesis, University of La Méditerranée Aix Marseille II Faculty of Medicine, Marseille, University of Szeged, Faculty of Science, Szeged, 263 pp.

Marcsik A 1998. Az ópusztaszeri csontvázanyag paleopatológiás elváltozásai. In L Gy Farkas, ÓpusztaszerMonostor Lelõhely Antropológiai Adatai, JATE Embertani tanszéke, Szeged, p. 97-154.

Marcsik A 2003a. Paleopatológiás jellegzetességek változása Észak Tiszántúlon a 10.-12. századból. MTA SzabolcsSzatmár-Bereg megyei Tud. Testületének kiadványa, Nyíregyháza, p. 133-136.

Marcsik A 2003b. Ibrány-Esbó halom X-XI. századi humán csontvázanyagának paleopatológiai jellegzetességei. In E Istvánovits, A Rétköz honfoglalás és Árpád-kori emlékanyaga, Nyíregyházi Jósa András Múzeum, MNM, MTA Régészeti Intézete, p. 392-399.

Marcsik A, Hegyi A 2004. Nyíregyháza-Manda bokor lelõhely humán csontanyagának paleopatológiás elváltozásai. JAMÉ XLVI: 247-261.

Marcsik A, Pálfi Gy 1999. Presence of infectious diseases in ancient populations in Hungary. Perspect Hum Biol 4: 159165.

Marcsik A, Szathmáry L 2002: Paleopatológiás elváltozások a szarmata korból, a gepida idõszakból és az avar korból. MTA Szabolcs-Szatmár-Bereg Megyei Tudományos Testület Kiadványa. Nyíregyháza, p. 80-84.

Marcsik A, Vékony L 1982. Pathological deformations of bones from the 8th century, Baèka-Topola, Jugoslavia. Proceedings of the 4th European Meeting of the Paleopathology Association, Middelburgh-Antwerpen (The Netherland), p. $126-130$.

Marcsik A, Szentgyörgyi R, Gyetvai A, Finnegan M, Pálfi Gy 1999. Probable Pott's paraplegia from the 7-8th century A.D. In GY Pálfi, O Dutour, J Deák, I Hutás (eds), Tuberculosis Past and Present, Golden Book Publisher, Budapest, p. 333-336.

Molnár E, Maczel M, Marcsik A, Pálfi Gy, Nerlich GA, Zink A 2005. A csont-ízületi tuberkulózis molekuláris biológiai vizsgálata egy középkori temetõ embertani anyagában. Folia Anthropol 3: 41-51.

Morse D 1961. Prehistoric tuberculosis in America. Am Rev 
Infec Dis 83: 489-504.

Ortner JO 2003. Identification of Pathological Conditions in Human Skeletal Remains, Academic Press, Amsterdam-Tokyo, 645 pp.

Rácz P 2004. Kecskemét-Gerõmajor 10-11. és DerekegyházIbolyásdomb 11-12. századi széria embertani feldolgozása, Diplomawork, Department of Anthropology, Szeged, 51 pp.

Pálfi Gy 2002. Papaleoepidemiological reconstruction of tuberculosis, with particular attention to Europe. Biennal Books of EAA 2: 193-210.

Pálfi Gy, Marcsik A 1999. Paleoepidemiological data of tuber- culosis in Hungary. In GY Pálfi, O Dutour, J Deák, I Hutás (eds), Tuberculosis Past and Present, Golden Book Publisher, Budapest, p. 533-542.

Pálfi Gy, Ardagna Y, Molnár E, Dutour O, Panuel M, Haas CJ, Zink A, Nerlich AG 1999. Coexistence of tuberculosis and ankylosing spondylitis in a 7-8th century specimen evidenced by molecular biology. In GY Pálfi, O Dutour, J Deák, I Hutás (eds), Tuberculosis Past and Present, Golden Book Publisher, Budapest, p. 403-409.

Szigeti T 2001. A Magyarhomoróg-Kónyadombi 10-11. századi temetõ vázcsontjainak metrikus és paleopatológiai feldolgozása, Diplomawork, Department of Anthropology, Szeged, 63 pp. 
